\title{
THE IMPLEMENTATION OF POSITIVE BEHAVIOR SUPPORT THROUGH CHAMPS TO IMPROVE STUDENT BEHAVIOR
}

\author{
Lupita Jane Suwandi \\ Program Studi Teknologi Pendidikan \\ Universitas Pelita Harapan \\ lupitajane@gmail.com
}

\begin{abstract}
An effective classroom is one that runs smoothly with a few disruptions. In fact, based on the observation at grade $4 \mathrm{XYZ}$ school, the researcher found that students frequently did inappropriate behavior such as calling out, excessive talking, forgetting to raise the hand quietly when asking question or stating an idea. One factor that made it happen was because the students did not clearly know about the teacher's behavior expectation. Facing these problems, the researcher decided to use a preventive way to minimalize the students' misbehavior using the CHAMPS approach which is a part of Positive Behavior Support. The purpose is to find out whether the students' behavior will be improved by the implementation of CHAMPS as an expectation before the lesson started. The method of this research was Classroom Action Research (CAR) which consisted of two cycles and involved 20 students. The instruments that used were the teacher's rating scale, student's attitude scale, and researcher's journal reflection. Descriptive statistical analysis and qualitative descriptive analysis were the technique used to analyze the data. From the data that has been analyzed, the researcher concluded that the implementation of Positive Behavior Support using CHAMPS had been improved student behavior in the classroom, specifically in their compliance towards the classroom rules and procedures. In short, despite its weaknesses and limitation, CHAMPS can be an alternative to minimalize students' misbehavior and improve students' behavior in the classroom.
\end{abstract}

Keywords: CHAMPS, positive behavior support, behavior, CAR

\section{INTRODUCTION}

The smoothness of learning is important to be analyzed since this topic closely deals with students' ability to learn effectively. Brophy and Evertson found in their findings that the teacher who reduced classroom disruption are associated with the increased of students' learning (Jones \& Jones, 2010). Therefore, in the school's setting, teachers as well as students are responsible for doing appropriate behavior because it will affect the potential and ability of students. The students are expected to behave appropriately because they are responsible for their actions. The role of the teacher is as instruments that lead them to do appropriate behavior in order to have a better future and create effective learning environment. 
The definition of behavior itself is part of dynamic psychology that can be shown in the attitudes, words, and actions (Djaali, 2013). Furthermore, O'Heare (2010) added that "Behavior is a response from individual to the environment that can be measured". The reason why student behavior is observable was because "It is not a result of personal problems but is normal developmental behaviors of children" (Levin \& Nolan, 2007). However, in the learning process the students often misbehave. In the book First Day of School, it is clearly stated that a vast majority of the behavior problems in the classroom are caused by the failure of the students to follow procedures and routines (Wong \& Wong, 2009). They also added three main reasons why students do not follow procedures. First, the teacher has not thought out what happens in the classroom. Second, the students have not been taught how to follow procedures. Third, the teacher spends no time managing the classroom with procedures (Wong \& Wong, 2009). From the reasons above, it can be noticed that one cause of misbehavior is due to the lack of good classroom management. Another reason why students misbehave is that they find themselves in environments that do not address their needs. (O'Donnell, Reeve, \& Smith, 2009).

Obviously, the classroom will not be effective if there is a lot of disruption and misbehavior of the student in the classroom. Related to the discussion above, the researcher found that the learning condition in fourth grade class, in XYZ school was not conducive. After several observations, the researcher found that the teacher had to spend more time and energy to remind or rebuke the students because they often misbehave. Some of misbehavior that they did were calling out, forgot to raise hand quietly when speaking or asking question, humming or singing in the lesson time, often going to the toilet or drinking when they did not really need it, and did not stay on task. To overcome this problem, the good classroom management is needed to control their behavior. In the matter of managing behavior, it is important to understand the meaning itself. "Managing behavior means setting up conditions that make desirable behaviors more likely to occur and undesirable ones less likely to occur" (O'Donnell, Reeve, \& Smith, 2009). Misbehavior of students is something that naturally happens and cannot be avoided in a classroom. However, teachers can do several techniques to increase desirable behaviors.

To overcome the problems, the researcher emphasized on the use of Positive Behavioral Support (PBS). It is a positive expectation in classroom behavior management that is designed by the teacher. Thus, it will help the teacher in prevent the misbehavior before the students do inappropriate behavior. The definition of Positive Behavior Support can be clearly seen if we split and look through each word. Positive behavior includes all skills that increase the likelihood of success and personal satisfaction in normative academic, work, social, recreational, community, and family settings. While, the support encompasses all educational and system change methods that can be used to teach, strengthen, and increase opportunities for the display of positive behavior (Carr, 2002). Through the definitions above, it can be concluded that Positive Behavior Support is a framework or approach that used to teach, reinforce, or reteach the appropriate behaviors. The purpose is to maximize the opportunity of the students in developing positive behavior in order to create safe, supportive, and conducive classroom. 
To be more specific, the researcher chooses the CHAMPS model as part of Positive Behavior Support to manage the classroom. Sprick (2009), as the pioneer of CHAMPS clearly stated that "CHAMPS is a systematic, prevention-oriented approach that guides teachers in providing universal classroom supports that are likely to promote appropriate behavior and reduce disruptive behavior in the classroom". CHAMPS is not a curriculum or program, but instead is a conceptual framework that are based on more than 30 years of research in the fields of education and psychology which is associated with student success (Sprick, 2009). CHAMPS address five categories in which expectations should be precisely taught. The $\mathrm{C}$ stands for Conversation (are students permitted to talk?), the $\mathrm{H}$ stands for Help (what should students do if they need assistance?), the A stands for Activity (what is the objective and end product?), the $\mathrm{M}$ stands for Movement (can students move around during the activity?), the $\mathrm{P}$ stands for Participation (how do students show that they are fully participating?), and the S stands for Success (Vitto, 2003). According to the definition above, it can be concluded that CHAMPS is an approach in the form of acronym to lead the students perform proper behavior so that it will prevent students' misbehavior. It consists of several expectations that stated in positive word. The purpose of CHAMPS itself is to build positive and effective classroom. The use of CHAMPS helps the teacher to make effective decisions in managing behavior while developing an instructional structure in which students are responsible, motivated, and highly engaged in the specific task at hand (Evans, 2016).

Some of the previous study below showed that the implementation of CHAMPS is useful in managing the students' behavior. In her dissertation research, Smith found that CHAMPS had an impact on student achievement both academically and behaviorally within that specific suburban elementary school (Smith, 2017). The implementation of CHAMPS was effective for students with Tier One behavioral issues, but not as effective for Tier Two or Tier Three behavioral issues (Dayan, 2013). In addition, previous study also suggests to explore CHAMPS strategy in urban learning environment (Back, 2016). Moreover, another study showed that CHAMPS had successfully guided the teacher participants in managing student behavior effectively. However, a limitation to that study was the participants were in one school and not examined district-wide (Evans, 2016). Based on the previous study above, this research was conducted directly to find out whether the implementation of Positive Behavior Support through CHAMPS can improve grade 4 student behavior in different country and school. This research will also strengthen the previous research whether CHAMPS can be one of the solutions to reduce students' disruptive behavior when it is implemented in different country from previous research.

\section{RESEARCH METHOD}

In this study the research design that used was Classroom Action Research (CAR). The CAR that is conducted by the researcher was a Practical Action Research. Teachers as the researcher seek to research the problem in their own classroom to improve students' learning and their own professional performance (Creswell, 2011). The researcher chose James McKernan (1996) model by considering a number of reasons. First, this model was made with earlier year. Second, a model of McKernan 
had more detailed steps in conducting the research. In every action cycle the research procedures are defining the problem, listing the needs of assessment, hypothesizing ideas, developing an action plan, implementing the plan, evaluating action, and finally making decisions. The model of McKernan (1996) visualized in the Figure 1.

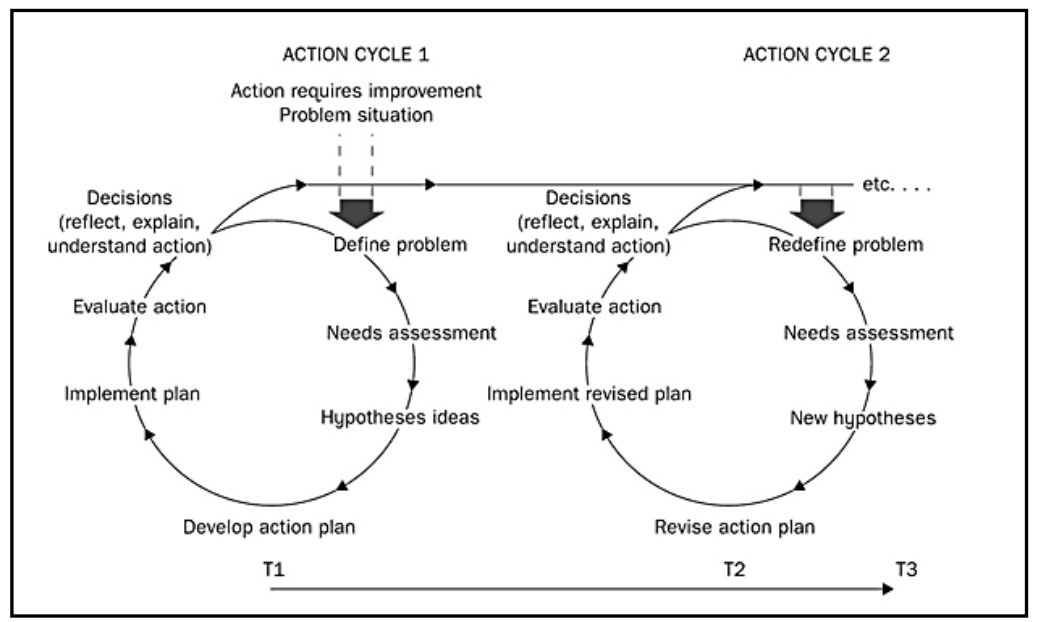

Figure 1. McKernan's Action Research Model 1996

Source: (Hopkins, 2014)

The minimum standard of this research was the students achieved at least 'good' for their behavior and the criteria for achieving 'good' is between 61-80 (Tampubolon, 2014). The interval conversion can be seen in the Table 1. In detail, the researcher added another standard in which the number of students who should pass the standard ('good') should be equal to or greater than 75\% (Djamarah \& Zain, 2013). Then, the researcher decided to conduct the next cycle to ensure the reliability to ensure the consistency and stability of data or findings (Sugiyono, 2009).

Table 1. Conversion of score

\begin{tabular}{cc}
\hline Interval & Criteria \\
\hline $81-100$ & Excellent \\
$61-80$ & Good \\
$41-60$ & Average \\
$21-40$ & Fair \\
$0-20$ & Poor \\
\hline
\end{tabular}

Source:(Tampubolon, 2014)

In this CAR, analysis of the data will be done in the form of qualitative and quantitative by using simple statistics. The quantitative data in this research describes certain number or percentage of aspects that is observed. The primary instrument is using rating scale to measure students' behavior. The data calculation is done by calculating each indicator by summing the total scores on each indicator then divided by the maximum score.

$$
P \quad=\begin{array}{lllllll}
t_{1} & s & & o & n s & \\
\hline m & & s_{1} & & \text { o } & n s & e^{\prime}
\end{array} 100 \%
$$


The other instrument is attitude scale sheet that is filled by the students and will be described in the form of a narrative using simple descriptive statistics. This instrument has a score from 0-10 and each number has its own meaning. The analysis of the data obtained from the respondents is calculated through the average by scoring each answer of the respondents (Sugiyono, 2009).

The indicator that is used to measure student's behavior is taken from the book Classroom Management for Elementary Teachers. There are two categories of student behavior that are important to monitor (1) student involvement in learning activities, (2) student compliance with classroom rules and procedures (Evertson, Emmer, \& Worsham, 2006). First, student involvement in learning activities is indicated by many behaviors. Therefore, the researcher had three statements to indicate the behavior of involvement in the classroom. (1) the student focuses in the lesson (being attentive in the lesson), (2) the student stays on task when he/she do his task, (3) the student contributes actively in the classroom discussion during the learning process. It means that the students also follow the teacher's instruction in each activity. Second, the indicator is about students' compliance in the learning activities. There are four statements that are used to support the indicator of students' compliance behavior (1) the student speaks at appropriate time with appropriate volume of speaking, (2) the student asks and answers question by raising his/her hands quietly, (3) when asking for help from the teacher, the student follows the procedure, (4) the student drinks and goes to the restroom only when they really need it. The indicator that is used in the instrument is shown in Table 2.

Table 2. Indicator of Students' Behavior

\begin{tabular}{lll}
\multicolumn{1}{c}{ Indicator } & \multicolumn{1}{c}{ Categories } & Code \\
\hline \multirow{2}{*}{ Indicator 1 } & Listen and pay attention & SB-LP \\
Students involvement & Stay on task & SB-ST \\
& Contribute actively & SB-CA \\
\hline \multirow{2}{*}{ Indicator 2 } & Speak at appropriate time & SB-SA \\
Students compliances with & Raise hand quietly & SB-RH \\
classroom rules and procedures & Follow procedure when need help & SB-FP \\
& $\begin{array}{l}\text { Drink or go to toilet only when } \\
\text { really need it }\end{array}$ & SB-DT \\
\hline
\end{tabular}

Source: modified from (Evertson, Emmer, \& Worsham, 2006)

\section{RESULT AND DISCUSSION}

The implementation of CHAMPS in the classroom for grade 4 students was done through two cycles. The cycle begins with defining the problem through the discussion of pre-cycle data which were observation log and also the questionnaire from the students and teacher's rating scale. In the pre-cycle stage the researcher asked help from other teacher to observe the students and the result percentage for the first indicator (student involvement) was $62.5 \%$ and for the second indicator (student compliance with rules and procedures) was $74.69 \%$. Based on this percentage, the student's behavior has reached the standard of behavior which is 'good'. However, the 
number of students who has not passed the standard which is 'good' was below $75 \%$, in the statements of listening and paying attention (SB-LP), staying on task (SB-ST), contributing actively (SB-CA), speaking at appropriate time (SB-SA), raising hand quietly (SB-RH), and following procedure when need help (SB-FP). So, the researcher started to implement CHAMPS as a solution to improve the desirable behavior from the students.

In the first cycle, the researcher started to implement CHAMPS. The lesson started by setting up CHAMPS board for the lesson. The researcher put the red check mark (with adhesive strapped) in every element that was chosen. The Conversation level was whispers voice. The students could talk but with whisper voice, it means only friends next to him/her who could hear the voice. The $\mathrm{H}$, if the students need help, they needed to raise hand quietly. The Activity for today was whole class discussion. For Movement, the students have stay in their seat and could go to bathroom or drink if they already need it. The Participation, keep working until finish and listen attentively (appendices 2 and for the second cycle see appendices 3). During the lesson, the other teacher observed the students' behavior by using rating scale. The teacher rated the behavior of every student with a score from 1 to 4 . The data will be used as a primary source and the result is shown in Table 3.

Table 3. Result of teacher's rating scale in cycle one

\begin{tabular}{|c|c|c|c|c|c|c|c|}
\hline \multirow{2}{*}{\multicolumn{4}{|c|}{ No Statement Total Score }} & Criteria & Max & Calculation & \multirow[t]{2}{*}{ Percentage } \\
\hline & & & & & & & \\
\hline 1 & SB-LP & $\begin{array}{c}62 \\
(77.5 \%)\end{array}$ & & Good & & & \\
\hline 2 & SB-ST & $\begin{array}{c}64 \\
(80 \%)\end{array}$ & 187 & Good & 240 & $\frac{1}{2} x$ & $\begin{array}{l}77.92 \% \\
\text { (Good) }\end{array}$ \\
\hline 3 & SB-CA & $\begin{array}{c}61 \\
(76.25 \%)\end{array}$ & & Good & & & \\
\hline \multicolumn{8}{|c|}{ Indicator 2 : Student compliances with classroom rules and procedures } \\
\hline 4 & SB-SA & $\begin{array}{c}60 \\
(75 \%)\end{array}$ & & Good & & & \\
\hline 5 & SB-RH & $\begin{array}{c}50 \\
(62.5 \%)\end{array}$ & 216 & Good & مO & 2 & $76.88 \%$ \\
\hline 6 & SB-FP & $\begin{array}{c}56 \\
(70.0 \%)\end{array}$ & 246 & Good & 320 & $\overline{3}$ & (Good) \\
\hline 7 & SB-DT & $\begin{array}{c}80 \\
(100 \%)\end{array}$ & & Excellent & & & \\
\hline
\end{tabular}

Source: Teacher's observation rating scale

From the first cycle, the lowest achievement is $62.5 \%$ which is about raising hand quietly if the students have question. The percentage of students who follow the procedures is $70 \%$, it is also below the minimum criteria. So, the researcher conducted the second cycle to see the consistency and the improvement of the students' behavior. The result in the second cycle is shown in Table 4. 
Table 4. Result of teacher's rating scale in cycle two

\begin{tabular}{|c|c|c|c|c|c|c|c|c|}
\hline No & Statement & Total Scor & & Criteria & Max & \multicolumn{2}{|c|}{ Calculation } & Percentage \\
\hline \multicolumn{9}{|c|}{ Indicator 1 : Student Involvement } \\
\hline 1 & SB-LP & $\begin{array}{c}65 \\
(81.25 \%)\end{array}$ & & Excellent & & & & \\
\hline 2 & SB-ST & $\begin{array}{c}66 \\
(82.5 \%)\end{array}$ & 194 & Excellent & 240 & $\frac{1}{2} x$ & $\%$ & $\begin{array}{c}80.83 \% \\
\text { (Excellent) }\end{array}$ \\
\hline 3 & SB-CA & $\begin{array}{c}63 \\
(78.75 \%)\end{array}$ & & Good & & & & \\
\hline \multicolumn{9}{|c|}{ Indicator 2 : Student compliances with classroom rules and procedures } \\
\hline 4 & SB-SA & $\begin{array}{c}62 \\
(77.5 \%)\end{array}$ & & Good & & & & \\
\hline 5 & SB-RH & 59 & & Good & & & & \\
\hline 6 & SB-FP & $\begin{array}{c}(73.75 \%) \\
65 \\
(81.25 \%)\end{array}$ & 266 & Excellent & 320 & $\frac{2}{3}$ & $\%$ & $\begin{array}{c}83.13 \% \\
\text { (Excellent) }\end{array}$ \\
\hline 7 & SB-DT & $\begin{array}{c}80 \\
(100 \%)\end{array}$ & & Excellent & & & & \\
\hline
\end{tabular}

Source: Teacher's observation rating scale

In the second cycle, the classroom management is getting better. The students' desired behavior also improved well. In the Table 5. below we can see the comparison between the pre-cycle, cycle one, and cycle two result.

Table 5. Result Comparison

\begin{tabular}{lccc}
\hline Indicator & Pre-cycle & Cycle 1 & Cycle 2 \\
\hline 1) Students Involvement & $62.5 \%$ & $77.92 \%$ & $80.83 \%$ \\
$\begin{array}{l}\text { 2) Students compliance with } \\
\text { rules and procedures }\end{array}$ & $74.69 \%$ & $76.88 \%$ & $83.13 \%$ \\
\hline
\end{tabular}

Source: Teacher's observation rating scale

The secondary instrument is filled by the students as a reflection toward their behavior. They fill it in the end of each cycle as shown in Table 6.

Table 6. Result of Student's Attitude Scale

\begin{tabular}{llcc}
\hline Variable & \multicolumn{1}{c}{ Indicator } & Cycle & Result \\
\hline & Indicator 1: & 1 & $70.5 \%$ (Good) \\
Students & Students Involvement & 2 & $74.83 \%$ (Good) \\
Behavior & $\begin{array}{l}\text { Indicator 2: } \\
\text { Students compliance with rules and } \\
\text { procedures }\end{array}$ & 1 & $72.25 \%$ (Good) \\
\hline
\end{tabular}

Source: Student's attitude scale sheet 
The previous research conducted by Gage et al. (2017) proved that there is a positive relation between the specific classroom management that is conducted by the teacher and student's outcome. Another research also suggested to clarify the relationship between classroom implementation of Positive Behavior Support and the outcomes (Childs, 2016). In this study, the specific classroom management used by the teacher is through CHAMPS. The results above show the improvement of student behavior in each cycle. In fact, the result of the first cycle has not meet the expectation. An evaluation is needed to implement better in the next cycle. So, after conducted the first cycle, the researcher reflected some weaknesses that found in cycle one. First, the time was too short for the students to learn a new thing. Even though the researcher has involved all of the students to repeat and model the CHAMPS but some students still were not really concerned with it. Hence, there were about three students who still often spoke directly without raised their hand quietly, stayed off-task, and sometimes talked with others. Second, the researcher still lacked of assertive in implementing this model. The researcher also reflects that during the implementation the researcher should directly praise the students who did the appropriate behavior so the others will be motivated to do their best. It is in accordance with the theory that if the students still have not showed the desired behaviors it means that they need further explanation, demonstration, or practice (Wong \& Wong, 2009). The teachers should reteach the correct behavior, give corrective feedback, and acknowledge the students when they meet the expectation. In conclusion, the researcher decided to continue the cycle and planned some improvements for the next cycle, they were: (1) emphasized more on the rationale or reason of doing appropriate behavior. (2) chose the students who often did not follow the desired behaviors to demonstrate the following expectations. (3) being firmer in acknowledging appropriate behavior and correcting the misbehavior. The improvement is made because in implementing classroom management plan such as CHAMPS model, it should be modified to fit current situations especially when something is not working the teacher should review the whole plan and made an improvement as a change that suit the needs in the classroom (Capizzi, 2009).

In the second cycle, the data result from teacher's rating scale was increased from 'good' to 'excellent' criteria. The percentage for this indicator was $80.83 \%$ (indicator 1) and $83.13 \%$ (indicator 2). From the result, we can see that CHAMPS is more effective to improve student's compliance with rules and procedures (Table 4.). Specifically, the students make an excellent criterion in following the procedure when they need help and also only drink or go to toilet when they really need it. Moreover, it was recorded that there was a student who rebuked her friend who called out for help from the teacher. As has been noted that the objective of good classroom management is that students encourage the others in their community to behave responsibly (Lewis, 2009). In this case, that student started to show awareness and responsibility towards the behavior expectation that has been set by the teacher. It could happen because the implementation of CHAMPS has been clearer and more assertive than in the first cycle. The researcher also gave specific feedback (praise and correction) to the students. It takes an important part in the CHAMPS implementation because providing feedback to students is essential to them in which teachers can communicate their expectations, evaluations, and encouragement of student progress (Trussell, 2008). 
The improvement in students compliance with rules and procedure was in accordance with the theory which said "Student compliance is closely related with the clear expectations for behavior" (Evertson et al., 2006). This is also consistent with the previous finding which reported that teachers with a good coping strategy such as rewarding the appropriate behavior and discuss with students about the misbehavior can minimize the level of student misbehavior better than using the aggressive disciplinary techniques (Tran, 2016).

Moreover, the important key during the implementation of Positive Behavior Support conducted by the teacher was the consistency. As the previous finding said that the implementation of Positive Behavior Support should be done with fidelity and consistency (Childs, 2016). Teachers need to stay focus on areas where small, definable change can be implemented with fidelity and durability when we implemented Positive Behavior Support (Horner \& Sugai, 2018). In the other words, during the implementation of CHAMPS to reduce student's disruptive behavior the researcher focused on the variables that has result in behavior change. During the implementation from cycle one to cycle two the researcher reflected that most of the students were improving even though it was not showing the significant improvement because the limitation of time however, the students become more responsive and motivated in doing expected behavior. Furthermore, most of the students were attentive, actively took notes, and contributed in the discussion. The positive climate during the learning process happened when the teacher implemented CHAMPS in the classroom. It is in accordance with the study that shows the relevance of using CHAMPS for positive school climate and academic achievement (Back et al., 2016).

Meanwhile, another study about the perception of CHAMPS implementation either from the teacher or students also proved that CHAMPS can be used as a tool to help the teacher in managing the classroom (Minnear, 2015). At first, about fifty-five teachers $(33 \%)$ agree that classroom management became their concern before they implemented CHAMPS. However, after the implementation of CHAMPS $60 \%$ teachers agree that CHAMPS has been helpful in improving their classroom management skills. The result of this research is in line with those findings. It proved that CHAMPS can be a mediator in helping the teachers manage the classroom and reducing students' disruptive behavior. Especially, for the expected behavior that teacher wanted to implement during the lesson. However, the ongoing training for all teachers was needed to have the same perceptions to implement CHAMPS better (Meidl, 2018).

Besides, there are some weaknesses during the implementation of CHAMPS. First, there was a distraction from one student who relapse his tantrum during the second cycle. It affected and disrupted the other students and may affect the result of the research. In addition, the researcher also did not have enough time to ask the students to model and restate the CHAMPS expectation, especially for students who often misbehaved. There is also a limitation of this study which is implemented in one class only. It would be better for the future study if it can be implemented in another class or the whole school as classroom management tools for the teachers. 


\section{CONCLUSION}

Through the research that has been conducted, the conclusion can be drawn to answer the research question. The implementation of Positive Behavior Support using CHAMPS could improve students' behavior in fourth grade class at XYZ School, Jakarta. Specifically, the improvement was in the second indicator which is compliance with the rules and behavioral expectations. The result from teacher's rating scale indicated that the students have improved their compliances to the behavior expectations from 'good' to 'excellent' category (83.13\%).

For the most part, the number of students who needed several times of reminder was also reduced. Through the implementation of Positive Behavior Support using CHAMPS most of the students have showed their involvement in listening attentively ( $80 \%$ or 16 students), staying on task ( $85 \%$ or 17 students), and actively contributing in the classroom discussion or activity ( $80 \%$ or 16 students). It was also in the student's compliance towards the behavioral expectations. The students who spoke with appropriate speaking level ( $90 \%$ or 18 students), quietly raised their hand before answer the question ( $70 \%$ or 14 students), followed the procedure when asking for help ( $90 \%$ or 18 students), and went to the restroom or drank only when they really need it (100\% or all of the students).

The implementation of Positive Behavior Support through CHAMPS approach can improve student behavior by applying five core elements of it, which are: identifying and defining expectations, teaching expectations, monitoring expected behavior, and acknowledging or encouraging expected behavior, correcting behavioral errors. In this research, CHAMPS is used as a boundaries and tool to prevent student's misbehavior. The important part is that the teacher should explain the rationale behind the expectations, give specific praise or correction, instill the right motivation in doing appropriate behavior, and the consistency in the implementation of it.

Furthermore, it is recommended that the school is willing to support the use of Positive Behavior Support with CHAMPS in the classroom and give training to the teacher about how to implement CHAMPS. It promotes positive outcome and can be an alternative approach to improve student behavior, prevent the misbehavior, maximize the learning time, and create an effective class. For the next research, it is suggested to train all of the teacher and implement it consistently and continuously.

\section{REFERENCES}

Back, L. T., Polk, E., Keys, C. B., \& McMahon, S. D. (2016). Classroom management, school staff relations, school climate, and academic achievement: testing a model with urban high schools. Learning Environments Research, 19(3), 397-410.

Capizzi, A. M. (2009). Start the year off right: Designing and evaluating a supportive classroom management plan. Focus on exceptional children, 42(3).

Carr, E. G., Dunlap, G., Horner, R. H., Koegel, R. L., Turnbull, A. P., Sailor, W., ... Fox, L. (2002). Positive Behavior Support: Evolution of an Applied Science. Journal of Positive Behavior Interventions, 4(1), 4-16. 
Creswell, J. W. (2011). Educational research: Planning, conducting, and evaluating quantitative and qualitative research (4th ed.). Boston, MA: Addison Wesley.

Childs, K. E., Kincaid, D., George, H. P., \& Gage, N. A. (2016). The Relationship Between School-Wide Implementation of Positive Behavior Intervention and Supports and Student Discipline Outcomes. Journal of Positive Behavior Interventions, 18(2), 89-99.

Dayan, R. (2013). Program evaluation of CHAMPS: School-wide Positive Behavioral Interventions and Supports (PBIS) at a therapeutic school. (Unpublished doctoral dissertation). Pace University, New York, NY.

Djaali, H. (2013). Psikologi pendidikan (Cet. 7). Jakarta: PT. Bumi Aksara.

Djamarah, S. B., \& Zain, A. (2013). Strategi Belajar Mengajar (cet. 5). Jakarta: Rineka Cipta.

Dunne, R., \& Wrag, T. (1996). Pembelajaran efektif. Jakarta: PT.Grasindo.

Evans, V. (2016). An evaluation of CHAMPS for classroom management. (Dissertation). Walden University.

Evertson, C. M., Emmer, E. T., \& Worsham, M. E. (2006). Classroom management for elementary teachers (7th ed.). Boston: Pearson.

Gage, N. A., Scott, T., Hirn, R., \& MacSuga-Gage, A. S. (2018). The Relationship Between Teachers' Implementation of Classroom Management Practices and Student Behavior in Elementary School. Behavioral Disorders, 43(2), 302-315.

Hopkins, D. (2014). A teacher's guide to classroom research (5th ed.). New York, NY: Open University Press.

Horner, R. H., \& Sugai, G. (2018). Future Directions for Positive Behavior Support: A Commentary. Journal of Positive Behavior Interventions, 20(1), 19-22.

Jones, L., \& Jones, V. F. (2010). Comprehensive classroom management: creating communities of support and solving problems (9th ed.). New Jersey: Pearson Education, Inc.

Levin, J., \& Nolan, J. F. (2007). Principles of classroom management: a professional decision-making model (5th ed.). United States: Pearson Education, Inc.

Lewis, R. (2009). Understanding pupil behaviour: classroom management techniques for teachers. New York, NY: Routledge.

Meidl, C., \& Vanorsdale, C. (2018). Application of PBS through CHAMPS. Educational Foundations, 31.

Minnear, Holly J., "An Evaluation of CHAMPS: A Classroom Management Program" (2015). (Dissertation). Gardner-Webb University School of Education.

O'Donnell, A. M., Reeve, J., \& Smith, J. K. (2009). Educational Psychology: Reflection for action (2nd ed.). United States: John Wiley \& Sons, Inc.

O'Heare, J. (2010). Changing Problem Behavior: A systematic and comprehensive approach to behavior change project management. Canada: Behave Tech Publishing. 
Smith, J. L. (2017). A study on the impact of the implementation of the behavior intervention support CHAMPS on students grades third through fifth within a large suburban elementary school. (Unpublished doctoral dissertation). St. Francis University, Loretto, PA.

Sprick, R. S. (2009). CHAMPS: A proactive and positive approach to classroom management (2nd ed.). Eugene, Or: Pacific Northwest Publishing.

Sugiyono. (2009). Metode penelitian kuantitatif, kualitatif, dan R\&D. Bandung: Alfabeta.

Tampubolon, S. M. (2014). Penelitian tindakan kelas untuk pengembangan profesi pendidik dan keilmuan. Jakarta: Erlangga.

Tran, V. D. (2016). Coping Styles with Student Misbehavior as Mediators of Teachers' Classroom Management Strategies. International Journal of Higher Education. 5(1), 1-10.

Trussell, R. P. (2008). Classroom Universals to Prevent Problem Behaviors. Intervention in School and Clinic, 43(3), 179-185.

Vitto, J. M. (2003). Relationship-driven classroom management: strategies that promote student motivation. Thousand Oaks, California: Corwin Press.

Wong, R. T., \& Wong, H. K. (2009). The first day of school: how to be an effective teacher (4th ed.). Mountain View, CA: Wong, Harry K. Publications. 


\section{APPENDICES}

Appendix 1. Students Attitude Scale

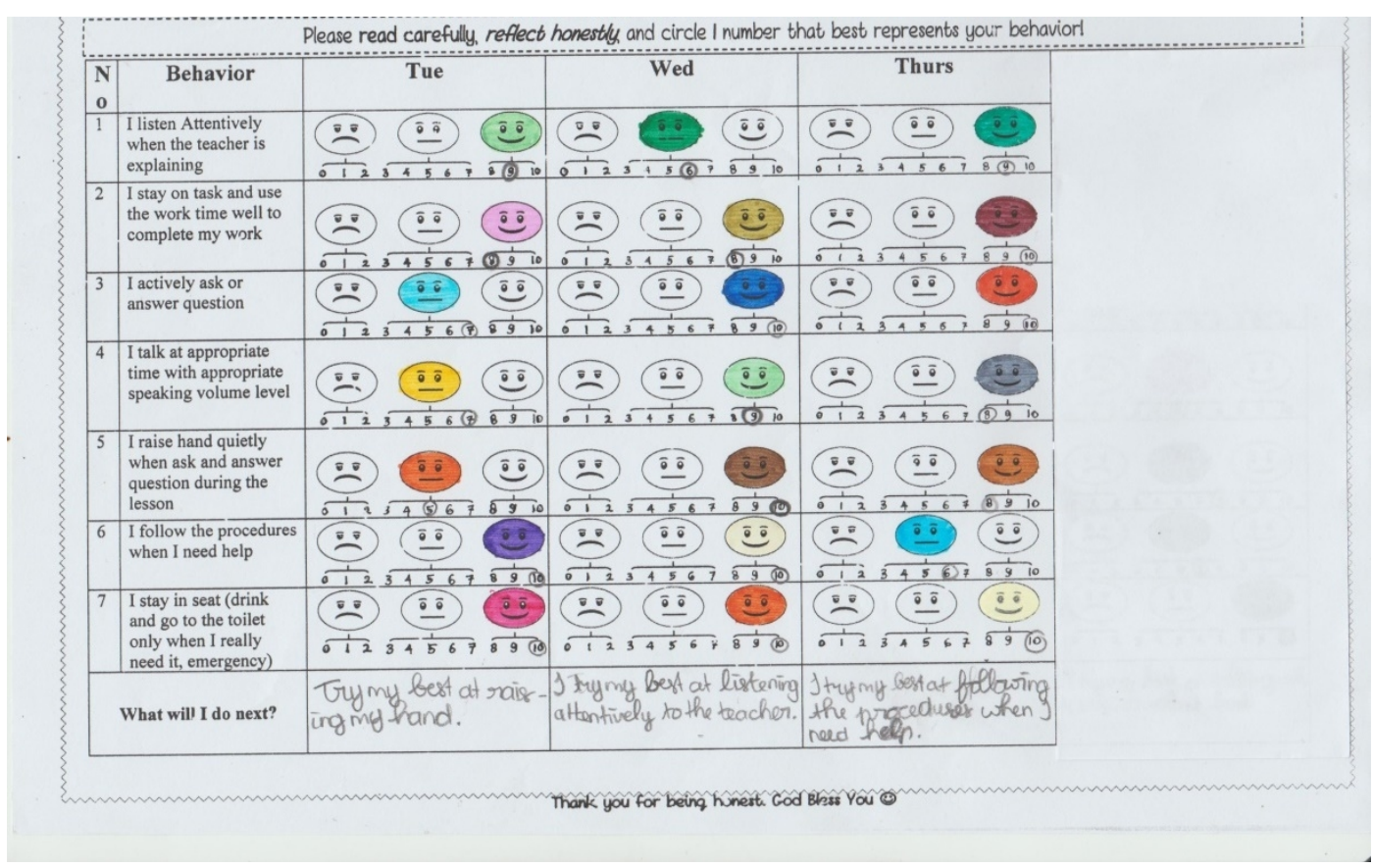

Appendix 2. CHAMPS Board Cycle 1

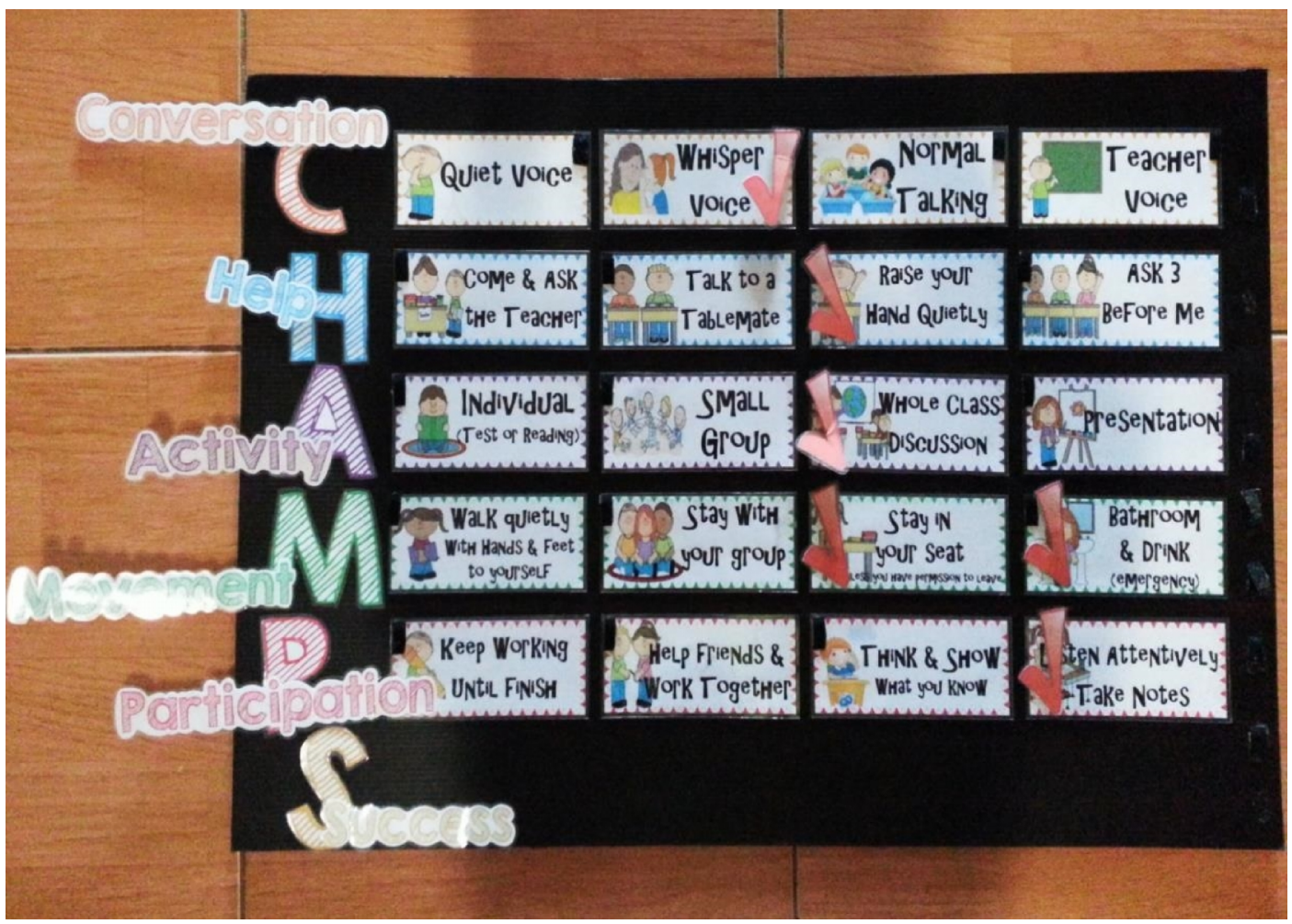


Appendix 3. CHAMPS Board Cycle 2

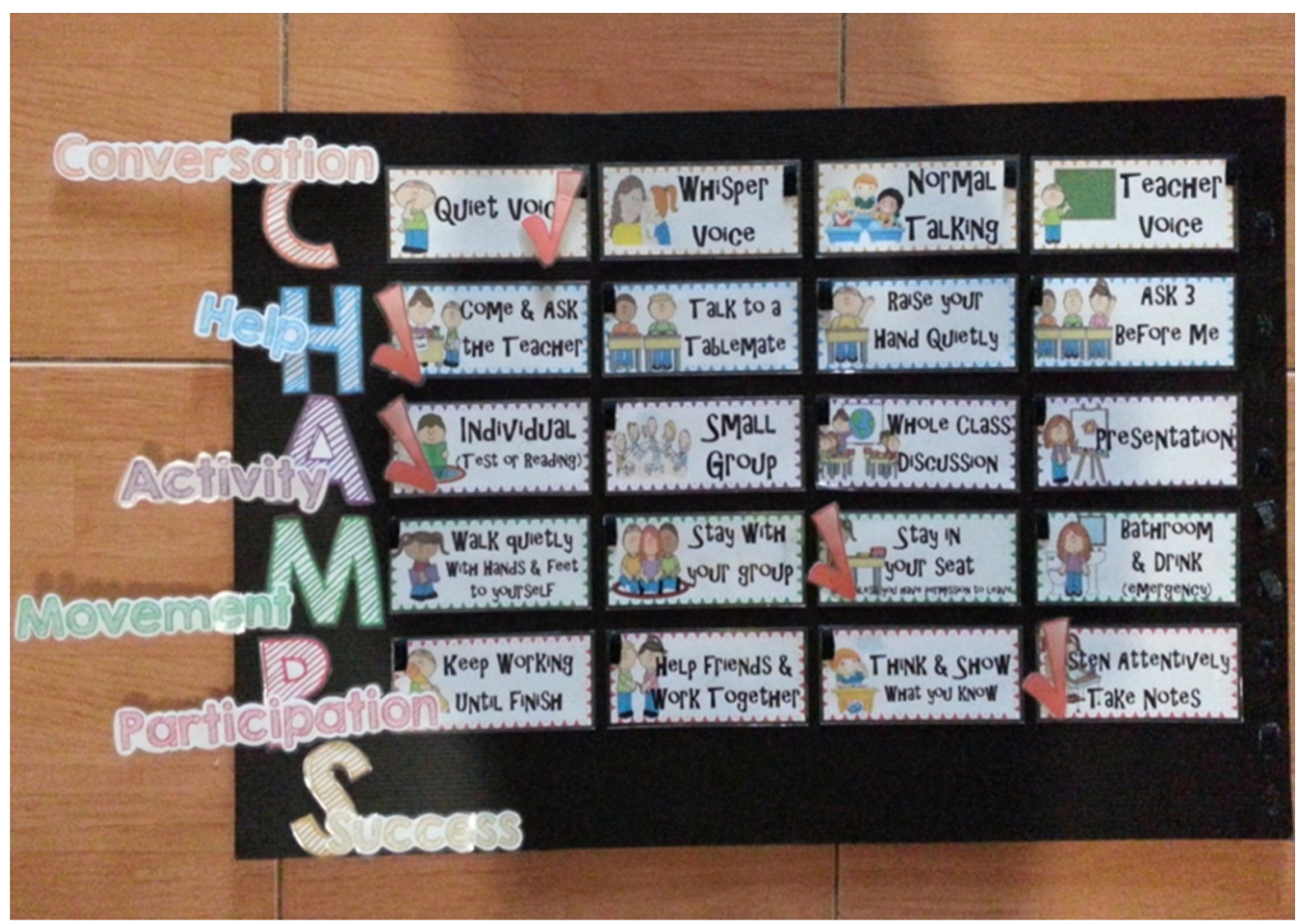

